\title{
Methodology on the Trend of Underlying Shariah Contracts and Legal Disputes of Decided Islamic Banking Cases in Malaysia
}

\author{
Nur Faakihin Ahmad Pauzi, Rusni Hassan, Safinar Mohd Salleh, Syed Ahmed Salman
}

\begin{abstract}
The general reflection of certainty and predictability in the decisions of the courts could be traced from the trend of decided Islamic Banking cases itself. Some studies highlighted the trend in decided Islamic Banking cases but not in detail, with a limited scope of discussion and did not cover the current and the latest decided cases. The objective of this paper is to provide a comprehensive analysis on the decided Islamic Banking cases in Malaysia of year 1987 to 2018 in order to find out the trend of underlying Shariah contract and legal disputes. The method employed in this study is the legal research through the analysis decided Islamic Banking cases in Malaysia. This paper highlights the underlying Shariah contracts that attract numerous judicial consideration and legal disputes in different phases of development in Islamic Banking cases. The diversification underlying Shariah contract and the complexity of legal issues could be traced in the more recent decided Islamic Banking cases. Moreover, the findings contribute to the enhancement of disputes resolution outcomes through court process and improvise the Shariah compliance and legal risk management of Islamic Banking Institutions.
\end{abstract}

Index Terms: Trend, Islamic Banking, Cases, Underlying Shariah Contracts, Legal disputes

\section{INTRODUCTION}

The rapid growth of Islamic Banking industry in Malaysia is a signal that the industry will expose the economy to the systemic risk if it is not properly controlled. Thus, this industry needs to be regulated to maintain its soundness and the sustainability of its progress. Well-defined strategies are needed focusing on the institutional capacity building and development of a comprehensive supporting financial structure. According to the former Governor of Central Bank of Malaysia, Datuk Zeti Akthar Aziz, legal infrastructure is one of the main pre-requisites in the Islamic Banking Sector Master Plan 2010 to 2020 (BNM, 2011). Enactment of new Islamic banking law and development of legal talents that are competent in both Shari'ah and Civil Law are the important parts of this process (Mohamad \& Trackic, 2012) In addition, the 10-year Financial Blue Print by the Central Bank of Malaysia aims to make the country as a global hub of Islamic Finance that focuses on developing Malaysia as a Centre of Reference (BNM, 2011). This includes the vision to enhance Malaysia's legal system in order to be acknowledged

\footnotetext{
Revised Manuscript Received on November 11, 2019.

Nur Faakihin Ahmad Pauzi, Master's Candidate at IIUM Institute of Islamic Banking and Finance, Malaysia

Rusni Hassan, Professor at IIUM Institute of Islamic Banking and Finance (IIiBF), International Islamic University Malaysia (IIUM)

Safinar Mohd Salleh, Assistant Professor at Ahmad Ibrahim Kulliyyah of Laws (AIKOL), International Islamic University Malaysia (IIUM).

Syed Ahmed Salman, Senior Lecturer at Faculty of Business and Accountancy, Lincoln University College, Malaysia
}

and adopted for the international Islamic financial transactions. To achieve this, according to Zakaria (2013), it requires among others, a comprehensive legal framework that could promise certainty, predictability, and consistency in the disputes resolution outcomes. Hence, the analysis on decided Islamic Banking cases is one way to come out with the inference and overview on the courts' adjudication of Islamic Banking cases in Malaysia. Notably, from time to time, the Islamic Banking institutions have moved to other new Shariah contracts to facilitate the financing transactions. The milestone of the Shariah contracts for Islamic Banks reveals the new adopted Shariah contracts from year 2009 onwards which include, Tawarruq, Parallel Istisna, Ijarah Mausufah fi Zimmah and others (BIMB, 2013). With the introduction to the new Shariah contracts, it suggests that different trends in Shariah contracts and legal disputes could be traced from decided Islamic Banking cases of year 1987 to 2018.

\section{UNDERLYING SHARIAH CONTRACTS IN ISLAMIC BANKING CASES}

The overall cases analysed in this study are 63 cases from year 1987 until 2018 of which they are divided into four phases: phase I from 1987-2003, phase II from 2004-2009, phase III from 2010-2012 and phase IV from 2013-2018. The category of the cases based on the Shariah underlying contract has revealed that 36 out of 63 cases deal with the Bai' Bithaman Ajil (BBA) contract. This covers $57 \%$ or half of the total cases. This finding is in line with Markom et al. (2013) and Hasan and Asutay (2011) that suggested, most of the decided Islamic Banking cases are related to the BBA contract. The percentage of different underlying Shariah contracts of 63 decided Islamic Banking cases analysed is illustrated in the following Diagram:

Diagram 1: Percentage of Different Underlying Shariah Contract in Decided Islamic Banking Cases of Year 1987-2018

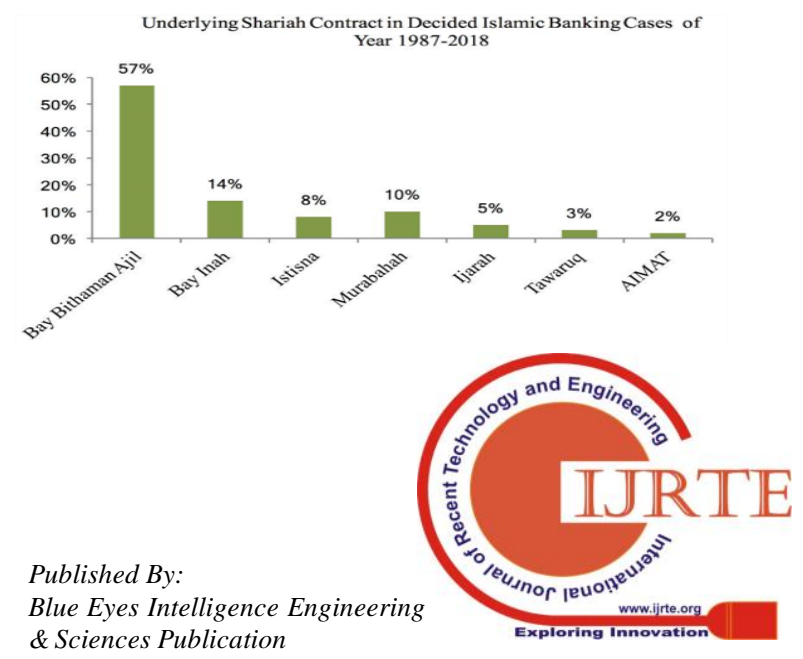


The finding indicates that the BBA contract and Bay' Inah are the two Shariah contracts that attract the most judicial consideration in the court litigation proceeding for Islamic Banking cases. The controversial over these two Shariah contracts have been addressed in many articles (Abdul \& Taib, 2009). It is observed from the cases that the disputes over the BBA contract are mainly centred on the Shariah issues.

In the early phases of decided Islamic Banking cases, the Shariah issues of the BBA contract mostly related to whether the Islamic Bank should be allowed to claim the full selling price in the case of early termination due to customers' default. This issue seems to be settled based on the Court of Appeal decision in case of Bank Islam Malaysia Bhd v Lim Kok Hoe \& Anor and other appeals (2009) that had granted the claim for the full selling price stipulated in the Property Sale Agreement (PSA) of the BBA contract. But, many still believe that it is unjust to allow the Islamic Banks to collect the "unearned profit" from the unexpired tenure of the financing. In Nurrachimi, Mohamed, \& Nazah(2013) mentioned that, in relation to the case of Bank Islam Malaysia Bhd v Lim Kok Hoe \& Anor and other appeals (2009) , the Court of Appeal Judges had decided in favour of the Islamic Bank in order to portray good image of Islamic Bank to the public and to prevent the injury to the growth of Islamic Banking industry in Malaysia.

However, it is argued that the decision of the court in the case was made based on the Islamic principles that the parties should be bound by the selling price that had been mutually agreed in the PSA. The decision did not in any way give good perception to the Islamic Bank. Many customers had turned away because the Islamic Banking seems to be more oppressive than the Conventional Banking (Mohamad \& Trakic, 2013). It is good to note that Bank Negara Malaysia in 2013 has issued the Guidelines on Ibra (Rebate) for sale based financing that requires the Islamic Financial Institutions to grant Ibra/rebate for early settlement of the financing including the cases involving the customers' default as stated under provision 6.1 of the Guidelines (BNM, 2013). By having this guideline, the courts now are able to do justice to the Islamic Banks as well as to the customers (Mohamad \& Trakic, 2013).

Another issue on the BBA contract in the more recent decided Islamic Banking cases is in relation to the existence of the subject matter of the contract in case of abandoned project. In the case of Pripih Permata Sdn Bhd v Bank Muamalat Malaysia Bhd (2015), the presiding Judge declared that the BBA contract entered by the parties as invalid due to the existence of Gharar Fahishah since there is uncertainty on the existence of the subject matter of contract because the construction of the building project was abandoned thus the court ordered the Islamic Bank in this case to refund the instalments paid by the customer. Although the decision in this case has been criticised due to the absence of any reference made to the SAC on the issue, but many agree that the Islamic Bank acting as the seller in the PSA should take the risk and obligation to ensure the completion of the project and the submission of vacant possession of the property to the customer (Hilal, Noor, \& Shuib, 2017).

Bay' Inah is the second Shariah contract that mostly disputed in Islamic Banking cases. The legal dispute on this contract is mostly on the Shariah issues. Based on the observation of 63 decided Islamic Banking cases, two cases involving the Bay' Inah have been declared by the court as invalid as in the case of Bank Kerjasama Rakyat Malaysia Bhd v MME Realty \& Management Sdn Bhd (2018) and FLH LCT Services SdnBhd\& Anor v Malaysian Debt Ventures Bhd (2016). In the first case, the Bay' Inah contract was declared as void because the agreement consists the pre-condition to repurchase the asset and in the second case the Bay' Inah contract was invalidated by the judge because of the absence of the underlying asset during the execution of the contract. Although the BBA contract is the highest underlying Shariah contract for Islamic Banking cases in every phase of the analysis, but the concentration of the BBA cases has reduced. In the first phase, of year 1987 to $2003,90 \%$ of the cases analysed are related to the BBA contract. But this percentage has continuously decreased. In the fourth phase of year 2013 to 2018, the percentage of the BBA contract in decided Islamic Banking cases is only 50\%. The underlying Shariah contracts in Islamic Banking cases become more diverse in the third and fourth phase and no longer monopolised by the BBA contract. This is mainly due to the action taken by the Islamic Banks that have stopped offering the BBA contract and move to other Shariah contracts like Tawaruq.

In some recent Islamic Bank's report, the division of the financing by Shariah contract has revealed that, over $80 \%$ of the underlying Shariah contracts for financing are based on Tawaruq and less than $20 \%$ of the underlying Shariah contracts are based on the BBA (Bank Islam, 2017). Although Tawaruq has been in the market since 2005 and currently becomes a phenomenal in the Islamic Banks, there are only two out of 63 decided Islamic Banking cases that deal with this Shariah contract.

\section{Diagram 2: Percentage of Underlying Shariah contract in Islamic Banking cases of}

Four Different Phases 1987-2018

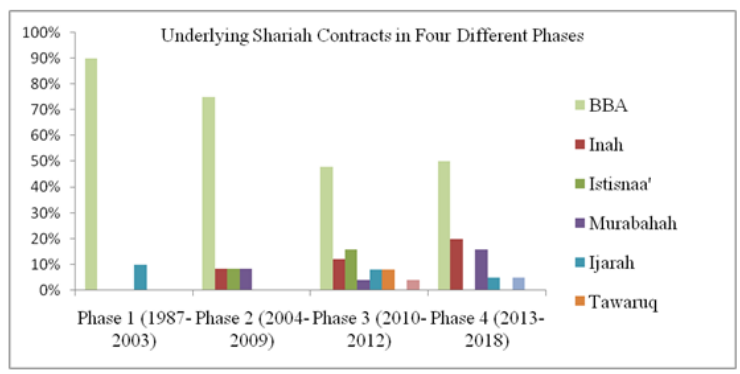

One of the main points that could be highlighted from the analysis is that over dependency on a particular controversial Shariah contract like the BBA in the past had resulted in higher legal and Shariah-compliance risk. This practice also had exposed the Islamic Banking institutions to the concentration risk when the legality of the Shariah contract from the Islamic perspective 
was questioned by the court. However, the Islamic Banking environment today has witnessed the domination of another Shariah contract which is Tawarruq in the financing transactions of Islamic Banking which is not a good indication. Thus, Islamic Banks should be encouraged to diversify the underlying Shariah contracts and minimise the application of controversial Shariah contracts in the financing transactions as a measure for risk mitigation process.

\subsection{Legal Disputes in Islamic Banking Cases}

According to Hasshan (2017), legal disputes in Islamic Banking could be divided into five main categories which include the contractual disputes, Shariah disputes, legislative disputes, procedural disputes and moral disputes. The finding of the legal issues in the cases that have been analysed are categorised into these five main groups. Through the observation and analysis of 63 decided Islamic Banking cases, it was observed that in many cases, there are more than one legal issues that had been submitted to the courts. The total number of legal issues that has been identified from the analysis of 63 Islamic Banking cases is amounted to 111 legal issues. The percentage of the legal issues that have been categorised based on the nature of the disputes into the five main categories is illustrated in the following diagram:

Diagram 3: Legal Disputes in Decided Islamic Banking Cases of Year 1987 to 2018

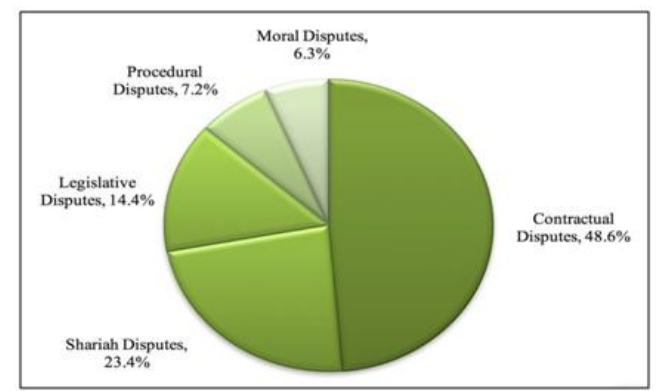

\subsection{Contractual Disputes}

The contractual dispute is initiated mainly due to the breach of contract. In relation to Islamic Banking cases, most of the proceedings were initiated by the Islamic Banks following the breach of the financing contract when the customers defaulted on the instalments. 44 out of 63 casesanalysed had named the Islamic Banks as the Plaintiffs that apply from the court either for Summary Judgment or Order for Sale to remedy the customers' default. This finding is in line with Markom et al. (2013) and Hasan and Asutay (2011), that have stated most of the cases in Islamic Banking involve the application for Summary Judgment and Order for Sale. In many cases, the courts granted the Summary Judgment and the Order for Sale to the Islamic Banks due to the failure of the customers to raise any defence or to prove the existence of any cause to contrary.

However, there are also cases initiated by the customer based on the contractual disputes. For example, in case of Tahan Steel Corp Sdn Bhd v Bank Islam Malaysia Bhd (2012) and Kamuja Hartamas SdnBhd (formerly known as Aras Suasana SdnBhd) v Bank Kerjasama Rakyat Malaysia Bhd (2017). The proceedings of these cases were initiated by the customers that had challenged the lawful action of the Islamic Bank in terminating the financing contract.

In addition, the contractual disputes also involve the matters under the Specific Relief Act (1950) such as the recession, rectification and specific performance (Hasshan, 2017). In the case of Malayan Banking Berhad v Robiah Binti Endot (2011), the issue of rectification on the profit rates that had been negligently written as $0.85 \%$ instead of the actual profit intended by the Islamic Bank of $8.5 \%$ was submitted to the court. The customer had been paying the instalments based on $0.85 \%$ profit rate for few years and innocently believe that the actually profit rate was $0.85 \%$. The court held that this was a unilateral mistake stemmed from the plaintiff's negligence and refused to grant the order of rectification.

\subsection{Shariah Disputes}

Through the observation, Shariah disputes are the most common defence raised by the customers against the claims by the Islamic Banks. This is in line with Hasshan (2017) that has stated most of the lawyers acting on behalf of the customers will submit on the Shariah issues to defence the cases. In many cases, the courts held that, the Shariah issues bought by the customers are not of bona fide issues to be trailed. It is unjust for the customers to raise the issue of Shariah non-compliance or illegality of the Shariah contract after benefitting from the financing. The Shariah issues raised were just the afterthought defence or mere allegations without any proof.

However, from the overall 63 cases that have been analysed, there are three cases in which the Islamic financing facilities agreements had been declared as void due to the Shariah disputes raised by the customer which include the case of Pripih Permata Sdn Bhd v Bank Muamalat Malaysia Bhd (2015), FLH LCT Services Sdn Bhd \& Anor v Malaysian Debt Ventures Bhd (2016), and Bank Kerjasama Rakyat Malaysia Bhd v MME Realty \& Management Sdn Bhd (2018).In these cases, the court found that the agreements are inconsistent with the fundamental Shariah requirements (see appendix 4).

\subsection{Legislative Disputes}

Legislative disputes are another common issue raised by the customers as defence against the claims by the Islamic Banks. The legislative disputes are related to the contention that the Shariah contracts entered by the parties had breach the statutory or legislative provisions. The judges faced a lot of difficulties to provide the findings and decisions on the legislative disputes raised by the parties in Islamic Banking cases (Hasshan, 2017). In dealing with this issue the courts have to look into the context of the provision and the intention of the legislature as mentioned by the judge in the case of CIMB Islamic Bank Bhd v LCL Corp Bhd\& Anor (2015).

From the cases that have been analysed, 16 legal issues have been recognised to fall under the legislative disputes. The example of significant legislative issue raised in 
decided Islamic Banking cases including the contention over the constitutionality of s. 56 and s. 57 of the Central Bank of Malaysia Act (2009) as found in the case of Tan Sri Abdul Khalid Ibrahim v Bank Islam (M) Bhd(2011) and Mohd Alias bin Ibrahim v RHB Bank Bhd \& Anor (2011). The conflict between the Shariah contract and the National Land Code (1965) also has been submitted to the courts in several cases including the case of Dato' Haji Nik Mahmud Bin Daud v Bank Islam Malaysia Berhad (1996) and Bank Muamalat Malaysia Bhd v Kong Sun Enterprise Sdn Bhd \& others (2012). Although in many cases, the courts have stressed on the applicability of the Contract Act (1950) to the Islamic financing, this does not prevent the customers from raising the issue on the conflict of the Shariah contracts and the Contract Act1950 (seeBank Kerjasama Rakyat Malaysia Berhad v Koperasi Belia Nasional Berhad, 2016)and (Bank Muamalat Malaysia Bhd \& Ors v Redha Resources SdnBhd\&Ors, 2017).

None of the courts' decisions in the cases involving the legislative disputes had agreed on the legislative conflict raised by the parties. Despite looking at the intention of the legislature on the enactment of the provision, the judges appreciate the unique characteristic of Shariah contract and try to construct the findings of the courts on the legislative issue in the perspective of Islamic principles (Bank Muamalat Malaysia Bhd v Kong Sun Enterprise Sdn Bhd \& others, 2012).

\subsection{Procedural Disputes}

Procedural disputes should not be considered lightly. Although the procedural disputes do not affect the merit of the case, there is still possibility that the courts may dismiss the application due to the non-fulfilment of the court procedure (Hasshan, 2017). Despite acknowledging the special characteristic of Islamic Banking facilities, the courts still held that the procedural requirement set by the law should be observed by the parties (Bank Islam Malaysia Berhad v Pasaraya Peladang SdnBhd, 2004).

Through the analysis, eight decided Islamic Banking cases had specifically dealt with the procedural issues. The usual procedural issues raised by the parties to Islamic Banking cases is related to the non-compliance of $\mathrm{O} 83 \mathrm{r} \mathrm{3(3)}$ of the Rules of Court 2012, that is to provide the definite amount claimed including the amount of interest in the application of Summary Judgment or Order for Sale as in the case of Bank Islam Malaysia Berhad v Adnan Bin Omar (1994) and Bank Islam Malaysia Berhad v Pasaraya Peladang SdnBhd (2004). In several cases, the judges refused to allow the parties to submit on the issues which were not specifically mentioned in the pleading as in the case of Bank Islam Malaysia Bhd v Aquasix Corp Sdn Bhd \&Ors(2014) and Bank Kerjasama Rakyat Malaysia Berhad v Koperasi Belia Nasional Berhad (2016). The court procedure requires the issues to be specifically raised and detailed in the pleadings before it could be submitted in the trial.

\subsection{Moral Disputes}

Moral disputes are related to the contentions or claims made by the parties based on the allegation of oppressiveness, excessiveness, fairness, justice, prohibited business conduct and consumer protection (Hasshan, 2017). In civil litigation process, the main consideration of the court is to deal with the legal issues pleaded and not to put any merit on the issue of morality. But in Islamic financial transactions, the issue of morality could not be disregard since morality is a significant element in Islamic principles. All the matters including the conducts and transactions are guided by the principle of morality such as fairness and justice as mentioned by the judge in the case of Malayan Banking Bhd v Ya' kup bin Oje \& Anor (2007). In the case of Amanah Raya Capital v Hairuddin \& Ors (2012), the judge had acknowledged the excessiveness of the Plaintiff in charging $6 \%$ rate of Tawidh on the customer.

Through the analysis, seven of the legal issues raised in 63 cases fall under the moral disputes. The contention of oppressiveness and excessiveness of Islamic Banks' claim usually interrelated with the Shariah issue on interest submitted to the court, (see Bank Kerjasama Rakyat Malaysia Bhd v Brampton Holdings Sdn Bhd (2015andAffin Bank Bhd v Zulkifli bin Abdullah (2006). By having section 135 and section 136 of the Islamic Financial Services Act2013, whereby the Islamic Banks are required to be transparent and fair in their contracts, the financial consumer may have a new ground to specifically claim or bringup the defence based on the issue of morality (Hasshan, 2017).

\section{CONCLUSION}

Through the analysis on decided Islamic Banking cases in Malaysia, it is interesting to highlight the increased sensitivity, concern and appreciation of the judges especially in dealing with the Shariah issues. The underlying Shariah contracts and the legal issues submitted to the courts in decided Islamic Banking cases have become more diverse and complex. Thus, the judges should be able to attend the issues with adequate knowledge on Islamic principles that govern the Islamic Banking practices, in order to ensure there is no flawed and strange decision. The improvement on these aspects will contribute to certainty, predictability and consistency in the dispute resolution outcomes of Islamic Banking cases through the court litigation proceeding. The readiness of the court to deliberate on the Shariah issues and to invalidate the Islamic Banking contracts due to Shariah non-compliance is an alert to the Islamic Banks to improve the Shariah compliance aspects. In addition, the analysis also reveals different scope of legal issues which include the legislative, procedural, moral disputes and others raised by the customers against the Islamic Bank. Thus, Islamic Banks should pay attention not only to Shariah compliance risk but also on the management of legal risks of the institutions.

\section{REFERENCES}

1. Affin Bank Bhd v Zulkifli bin Abdullah [2006] 3 MLJ 67

2. Amanah Raya Capital v Hairuddin\&Ors [2012] 5 CLJ 651

3. Bank Kerjasama Rakyat Malaysia Bhd v Brampton Holdings Sdn Bhd [2015] 4 CLJ 635

\section{Published By:}


4. Bank Islam Malaysia Bhd v Aquasix Corp SdnBhd\&Ors [2014] 3 MLJ 812

5. Bank IslamMalaysia Berhad v PasarayaPeladangSdnBhd [2004] 7 MLJ 355

6. Bank Islam Malaysia Berhad v Adnan Bin Omar [1994] 3 CLJ 735

7. Bank Muamalat Malaysia Bhd v Kong Sun Enterprise Sdn Bhd \& others [2012] 10 MLJ 665

8. Bank Muamalat Malaysia Bhd\&Ors v Redha Resources SdnBhd\&Ors [2017] 2 MLJ 686

9. Bank Islam Malaysia Bhd v Lim Kok Hoe \& Anor and other appeals [2009] 6 MLJ 839

10. Bank Negara Malaysia. (2011). Financial Sector Blueprint 2011-2020 Strengthening Our Future, LXIX(4), 1-198. https://doi.org/10.1080/00346764.2011.592329

11. Bank Negara Malaysia (BNM). (2013). Guideline on Ibra' (Rebate) for Sale-Based Financing,2013 (November 2011), 21.

12. BIMB. (2013). Application of Shariah Contracts in Bank Islam's Products and Services. Bank Islam Malaysia Berhad.

13. Central Bank of Malaysia Act (2009)

14. Contract Act 1950

15. Dato' Haji Nik Mahmud Bin Daud v Bank Islam Malaysia Berhad [1996] 4 MLJ 295Federal Constitution of Malaysia

16. Hilal, N., Noor, F. M., \&Shuib, M. S. (2017). Issues in Bay' Bithaman Al-Ajil Islamic Home Finance ("BBA") in Abandoned Housing Projects In Malaysia : An Examination of cases. Journal of Law, Policy and Globalization, 57(February), 122-132.

17. Hasan, Z, \&Asutay, M. (2011). An analysis of the courts' decisions on islamic finance disputes. ISRA International Journal of Islamic Finance, 3(2), 41-71. Retrieved from http://papers.ssrn.com/sol3/papers.cfm?abstract_id=2089817

18. Hassan, R. (2011). The Establishment of Muamalah court in malaysia: AnQverview of Issues andChallenges. IIUM Law Journal, Special Ed(December 2011).

19. Hasshan, H. (2017). Islamic Finance Litigation In Malaysia: An Overview. CLG Law Legal NetworkSeries, 1(LNS(A)xxix), 1-9.

20. Islamic Financial Services Act (2013)

21. KamujaHartamasSdnBhd (formerly known as Aras SuasanaSdnBhd) v Bank KerjasamaRakyat MalaysiaBhd [2017] 3 MLJ 668

22. Mohd Alias bin Ibrahim v RHB Bank Bhd\& Anor [2011] 3 MLJ 26

23. Malayan Banking Berhad v Robiah Binti Endot [2011] 1 LNS 1499

24. Mohamad, A. H., \& Trakic, A. (2013). Granting of Ibra ' by Islamic Banks in Malaysia : A Matter ofDiscretion or Obligation? Journal of International Banking Law and Regulation, (9).

25. Markom, R., Pitchay, S. A., Zainol, Z. A., Rahim, A. A., \&Merican, R. M. A. R. (2013). Adjudication of Islamic banking and finance cases in the civil courts of Malaysia. European Journal of Law and Economics, 36(1), 1-34. https://doi.org/10.1007/s10657 011-9249-4

26. National Land Code (1965)

27. Nurrachimi, R., Mohamed, H., \& Nazah, N. (2013). Dispute between Bank and Customer in Bai Bithaman Ajil (BBA). Case in Malaysia. Munich Personal RePEc Archive (MPRA), (10679).Retrieved from https://mpra.ub.uni-muenchen.de/43991

28. Pripih Permata Sdn Bhd v Bank Muamalat Malaysia Bhd [2015] 6 CLJ 135

29. Rules of Court 2012

30. Tan Sri Abdul Khalid bin Ibrahim v Bank Islam Malaysia Bhd and another suit [2009] 6 MLJ 416TahanSteel Corp Sdn Bhd v Bank Islam Malaysia Bhd [2012] 2 MLJ 314

31. Zakaria, A. (2013). a Judicial Perspective on Islamic. IIUM Law Journal, 21(2), $143-182$. https://doi.org/http://dx.doi.org/10.1108/17506200710779521

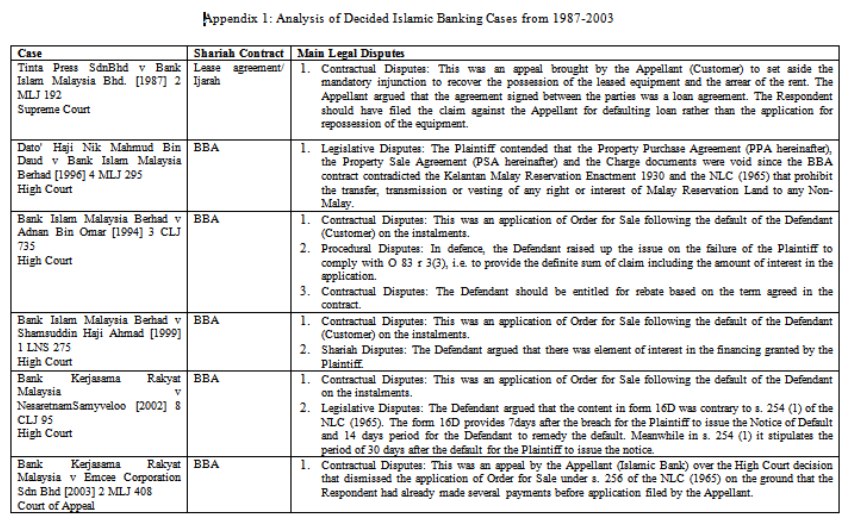

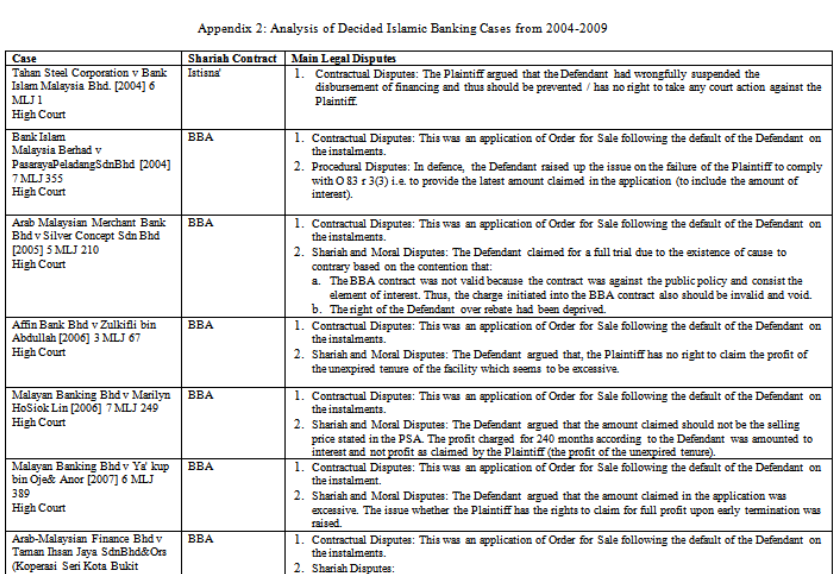
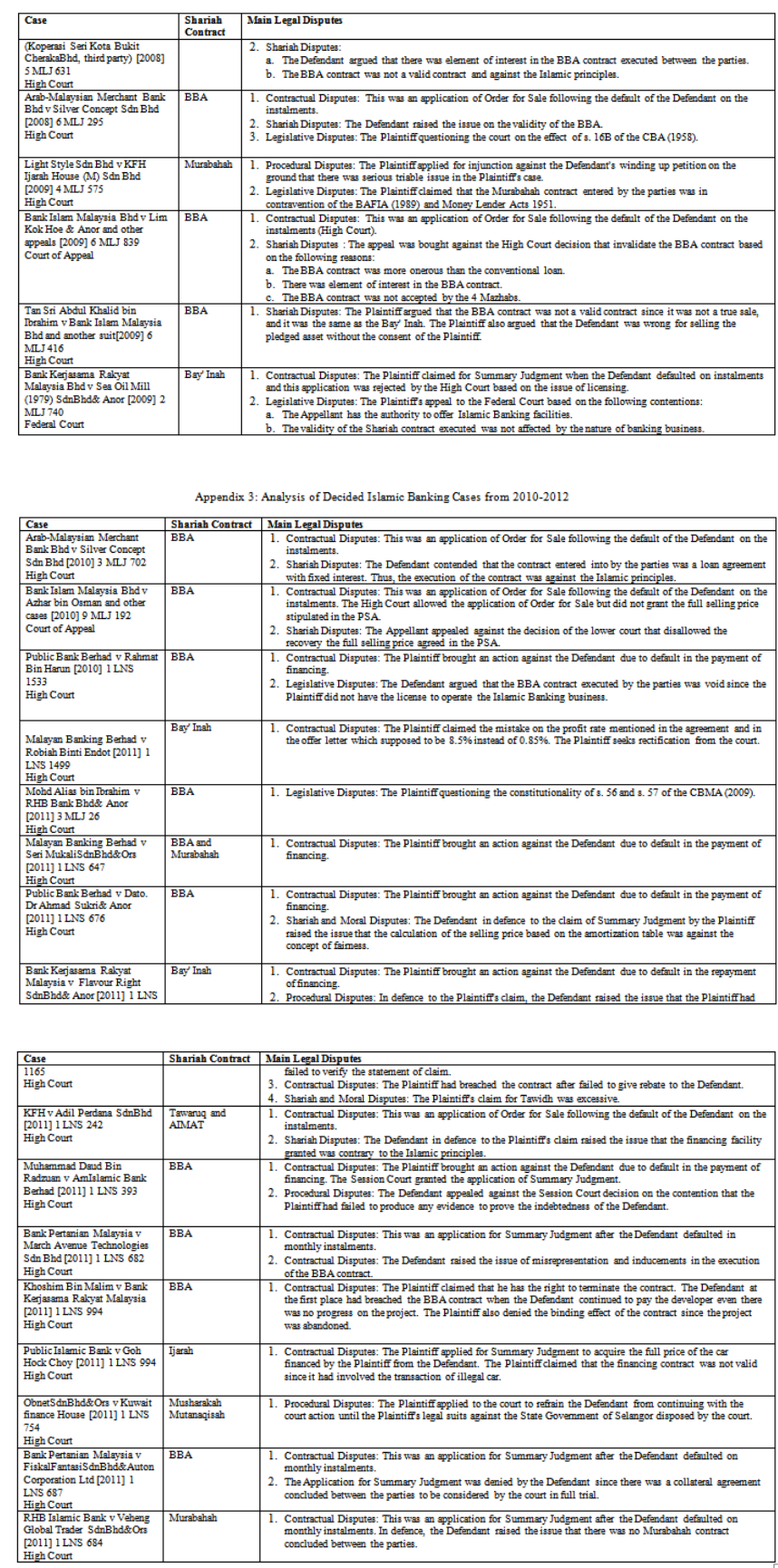

Published By: 
Methodology on the Trend of Underlying Shariah Contracts and Legal Disputes of Decided Islamic Banking Cases in Malaysia
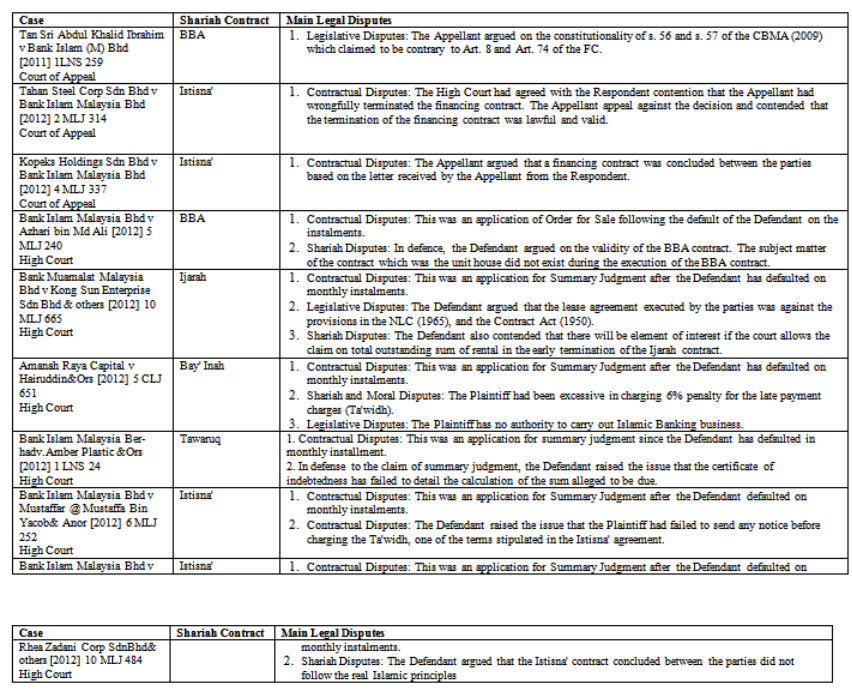

Appendix 4: Analysis of Decided Islamic Banking Cases from 2013-2018
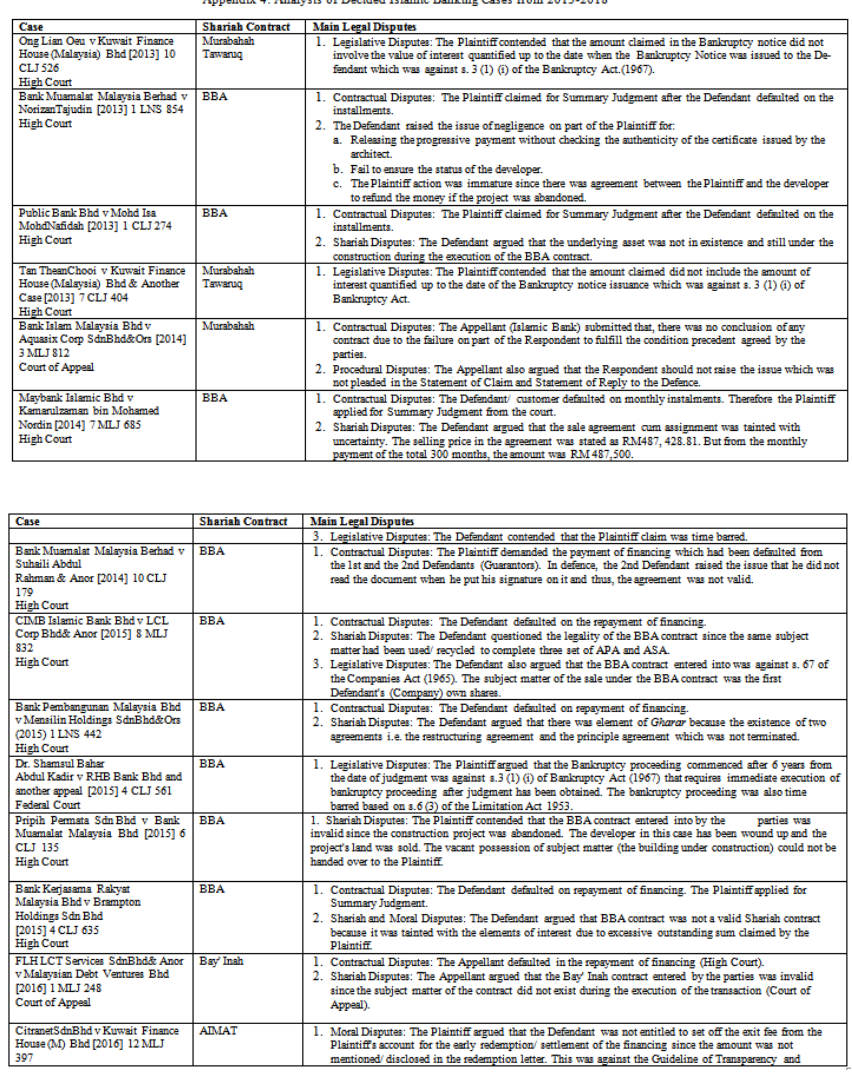

\begin{tabular}{|c|c|c|}
\hline & contract & 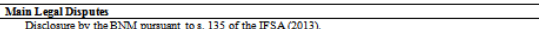 \\
\hline 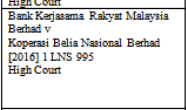 & Bagl tinah & 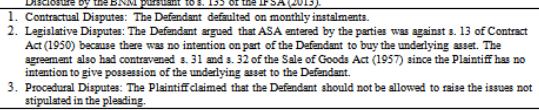 \\
\hline 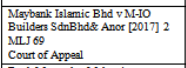 & $\begin{array}{l}\text { Murabalath } \\
\end{array}$ & 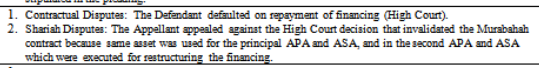 \\
\hline 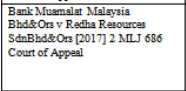 & Begl Imath & 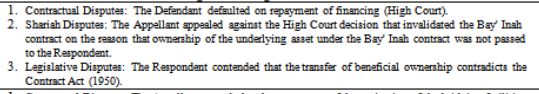 \\
\hline 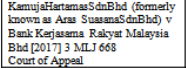 & BBA & 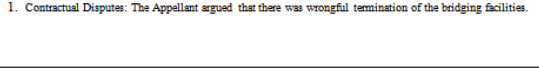 \\
\hline 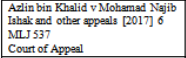 & Ijistah & 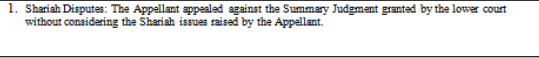 \\
\hline 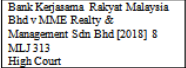 & Besy Inah & 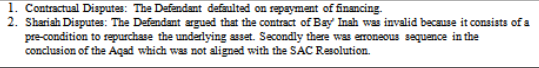 \\
\hline
\end{tabular}

